\title{
Drug Office Wins Friends, Disurms Enemies
}

by our Washington Correspondent

ONLY two short months have now gone by since President Nixon announced to Congress and the nation his war against drug abuse, and already two Congressional committees have concluded hearings on legislation designed to put into effect his package deal setting up a Special Action Office for Drug Abuse Control, with additional funding of $\$ 155$ million for the control of drugs and the rehabilitation of addicts. Both committees-the House Subcommittee on Public Health and Environment and the Senate Subcommittee on Intergovernmental Relations-are expected to report to Congress soon after the recess, and it seems from the evidence submitted to the committees that the President's proposals should emerge substantially unchanged. The programme has met with approval even from the agencies whose work will be subordinated to the new special action office.

Chief among the tasks of the proposed action office is to coordinate the federal programmes for drug control and rehabilitation, at present spread over nine agencies of the Federal Government. To accomplish this task, the Special Action Office will have at its disposal the effective and overtly simple expedient of complete budgetary control over all federal drug abuse programmes. But creation of the special action office will also underline a marked shift in the government's attitude to drug control, for in the past it has relied heavily on the courts to deter potential addicts from taking drugs, often at the expense of seeming to neglect the other side of the cointhe rehabilitation of existing addicts. Only the full realization of the extent of heroin addiction among troops in Vietnam which came to light about a year ago, and the potential impact of thousands of addicts returning to the United States from Asia has led to the tardy adoption of a crash programme aimed at rehabilitation.

While the new emphasis away from severe court action brought against drug users and towards education and rehabilitation has been widely applauded, there are still many doubts surrounding the way in which the new special action office will function. One such doubt is whether the director of the office will be able to exercise complete control over the budgets of the agencies in his jurisdiction without at the same time running up against resentment within the agencies themselves at their loss of effective power. As James W.
Symington, a member of the Subcommittee on Public Health and Environment, said to Dr Jerome $\mathbf{H}$. Jaffe, Nixon's nominee to head the action office, "in every one of those agencies there is a fellow that has the responsibility right now to see how much they can afford, where it ought to go, and how he exercises that responsibility depends on the multiplicity of contacts that agency has in the states and localities. But you are going to understand all of that for every agency, put it together and then explain to them how to handle it. Congratulations and best wishes".

In many respects, the appointment of Dr Jaffe to the post of director has circumvented a few of those fears, for $\mathrm{Jaffe}$ is respected by all the agencies with which he will be dealing. In particular, he has served for several years on the board of the National Institute of Mental Health, whose Division of Narcotic Addiction and Drug Abuse will consume some 70 per cent of the Special Action Office's funds. During that time, Jaffe has built up a strong working relationship with the NIMH staff which will stand him in good stead for regulating their budgets. One official of the NIMH said last week that he regards the special action office as a powerful ally to fight for funds and that there should be no problem in the transfer of power from the NIMH to its drug overlord.

How Jaffe visualizes the work of the special action office became clear during his second appearance before the subcommittee earlier this month. He explained that the office would not seek to meddle closely in the work of the various agencies, and that it would take over the running of a particular programme only as a last resort. The office is therefore intended to be an overlord, working chiefly by informal contact and discussion with the members of the agencies under its control, acting as their mouthpiece in Congressional hearings, and using its powers to seek appropriations for drug abuse control and to distribute federal monies.

Applications for funding for new projects will be channelled through the office, and Jaffe will be concerned especially to see that there is no duplication of effort among federal agencies. The arrangement also has the potential advantage that it may help to speed up the adoption and funding for new projects, for they will no longer be buried within the bureaucratic layers of each individual federal agency.
If the house subcommittee on Public Health and Environment does alter the Administration's legislation, it seems likely that the powers of the proposed special action office will be widened rather than cut down, for there has been some disquiet that the Department of Defense is not includea among the Federal agencies controlled by the office. Jaffe, however, has said that there would be no particular advantage in his having budgetary control over the Defense Department's drug abuse programmes, because any necessary coordination can be achieved by informal discussion.

One aspect of the drug problem in which the attitude of the Department of Defense is particularly important, however, is to establish the terms under which a member of the armed services is given a dishonourable discharge. In the past, services personnel have been given a dishonourable discharge for drug addiction, and this has prevented them from receiving treatment in the clinics run by the Veterans Administration.

There is also the problem of administering tests on servicemen for the presence of opiates in the urine, prior to discharge. It has recently been found from such tests that 5.4 per cent of American servicemen in Vietnam had used heroin in the two days before the test was given. The test, which was given on a random basis, almost certainly provided an underestimate of the number of servicemen taking hard drugs, and Jaffe himself believes that the true figure is probably nearer 10 per cent. It therefore seems likely that the subcommittee will add the Defense Department to the legislation in the hope that the Special Action Office will be able to coordinate not only the testing of American servicemen for the presence of hard drugs, but also the treatment of addicts in the armed services.

If the Special Action Office is set up, it will have an initial lifespan of three years, when its operations will be reviewed by the President. There is little in either the proposed legislation or in the steadily increasing figures for drug addiction-it is estimated that there are now about 250,000 heroin addicts in the United States, and probably 150,000 in New York alone-to suggest that the problem will be any less acute in 1974. But at least a change of direction in favour of rehabilitation is a comforting sign of the Administration's intentions. 